\title{
Mycotoxins-Prevention, Detection, Impact on Animal Health
}

\author{
Jagoda Kępińska-Pacelik and Wioletta Biel *(1)
}

check for

updates

Citation: Kępińska-Pacelik, J.; Biel,

W. Mycotoxins-Prevention,

Detection, Impact on Animal Health.

Processes 2021, 9, 2035. https://

doi.org/10.3390/pr9112035

Academic Editors: Manuela Zadravec and Jelka Pleadin

Received: 2 October 2021

Accepted: 10 November 2021

Published: 14 November 2021

Publisher's Note: MDPI stays neutral with regard to jurisdictional claims in published maps and institutional affiliations.

Copyright: (c) 2021 by the authors. Licensee MDPI, Basel, Switzerland. This article is an open access article distributed under the terms and conditions of the Creative Commons Attribution (CC BY) license (https:/ / creativecommons.org/licenses/by/ $4.0 /)$.
Department of Monogastric Animal Sciences, Division of Animal Nutrition and Food, West Pomeranian University of Technology in Szczecin, Klemensa Janickiego 29, 71-270 Szczecin, Poland; jagoda.kepinska-pacelik@zut.edu.pl

* Correspondence: wioletta.biel@zut.edu.pl

\begin{abstract}
Mycotoxins are defined as secondary metabolites of some species of mold fungi. They are present in many foods consumed by animals. Moreover, they most often contaminate products of plant and animal origin. Fungi of genera Fusarium, Aspergillus, and Penicillum are most often responsible for the production of mycotoxins. They release toxic compounds that, when properly accumulated, can affect many aspects of breeding, such as reproduction and immunity, as well as the overall liver detoxification performance of animals. Mycotoxins, which are chemical compounds, are extremely difficult to remove due to their natural resistance to mechanical, thermal, and chemical factors. Modern methods of analysis allow the detection of the presence of mycotoxins and determine the level of contamination with them, both in raw materials and in foods. Various food processes that can affect mycotoxins include cleaning, grinding, brewing, cooking, baking, frying, flaking, and extrusion. Most feeding processes have a variable effect on mycotoxins, with those that use high temperatures having the greatest influence. Unfortunately, all these processes significantly reduce mycotoxin amounts, but they do not completely eliminate them. This article presents the risks associated with the presence of mycotoxins in foods and the methods of their detection and prevention.
\end{abstract}

Keywords: aquaculture animals; companion animals; detection; farm animals; mycotoxin; prevention; safety

\section{Mycotoxins}

Mycotoxins are defined as secondary metabolites of some fungi species. They are present in agricultural commodities and are produced by certain fungi with adverse acute and chronic effects such as genotoxicity and carcinogenicity on humans and animals $[1,2]$. The name "mycotoxin" is derived from the Greek word mycos (fungi) and Latin toxicum (poison). They are most often produced by fungi of the genera Aspergillus, Penicillium, Fusarium, and Alternaria [3] (Figure 1). Their synthesis depends largely on the internal parameters of fungal strains (physiological, genetic, and biochemical) [4] but also external factors such as temperature and humidity [5]. This means that the level of mold contamination depends, inter alia, on local weather conditions because high air humidity is conducive to their formation. Most often, mycotoxins are a contamination of plant-based products such as cereals, vegetables, dried fruit, nuts, coffee, cocoa, and tea. They can be present even in wine and beer [6].

However, not only plant products can be a source of mycotoxins. This also applies to raw materials and products of animal origin (e.g., milk, meat) [7-9]. Moreover, it is believed that organic products are more likely to be contaminated with mycotoxins than conventional products due to the non-use of synthetic fungicides in their cultivation. However, in organic farming, cultivars resistant to toxin-producing fungi are selected for cultivation, and in addition, the use of appropriate crop rotation prevents the formation of mycotoxins in agricultural crops [10]. Organic milk also runs the risk of being more contaminated than conventional milk. Studies [11] have shown that $\mathrm{M}_{1}$ aflatoxin contamination in some, 
but not all, organic milk samples were significantly higher than that of conventional milk, although factors other than organic production may be involved.
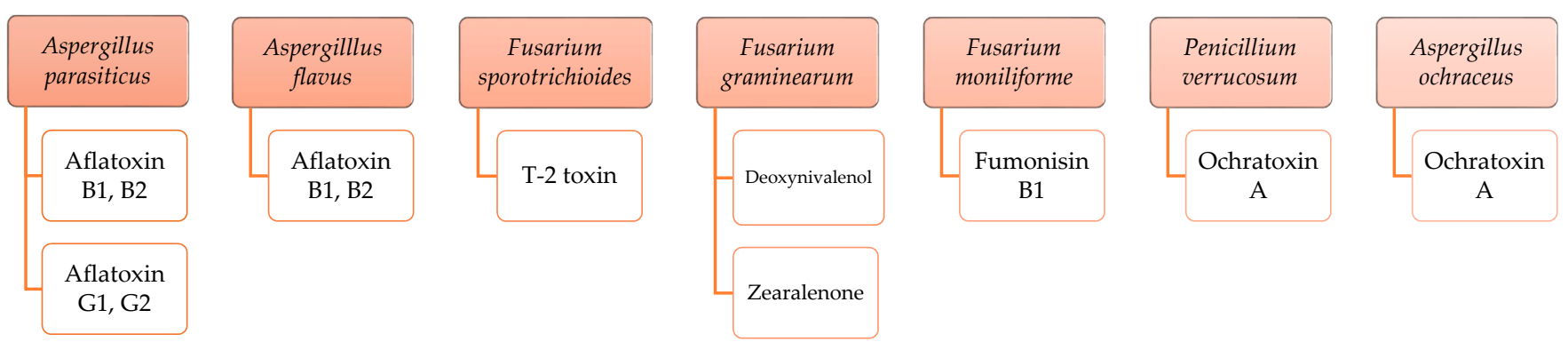

Figure 1. Fungi species and mycotoxins produced of world-wide importance. Adapted from [12,13].

Many mycotoxins have been characterized, but the most important in terms of food safety are aflatoxins, deoxynivalenol, fumonisins, zearalenone, and ochratoxin A [14]. These basic forms of mycotoxins can be converted into products with altered chemical structures with different properties, such as physicochemical, chemical, and biological. Modified forms may arise in raw materials intended for food production and during technological processes [15]. Modified mycotoxins can also be produced by fungi or as part of an infected plant's defense mechanism $[4,16]$. The interest in mycotoxins results mainly from their physicochemical properties-high stability in changing environmental conditions and high toxicity. Even a small number of mycotoxins in food can lead to serious health consequences, especially because as low-molecular and thermostable substances they are resistant to most technological processes, e.g., cooking, frying, baking, distillation, and fermentation [17].

\section{Prevention}

The increasing availability of modern and efficient techniques greatly facilitates the rapid expansion of data on the biology of mycotoxin-producing fungi [18]. Combining datasets with advanced computational methods, including analysis of a range of genome sequencing projects that are focused on fungal plant pathogens, has a positive impact on the current state of knowledge available [19]. Thanks to this, it is possible to increase the knowledge of scientists in the field of molecular processes that regulate the production of mycotoxins $[20,21]$. There are studies to determine the relationship between water activity $\left(a_{\mathrm{W}}\right)$ and temperature on growth and mycotoxin synthesis under specific environmental conditions, which induces scientists to associate appropriate conditions with the risk of mycotoxin development [22]. The optimal environmental conditions for the development of fungal species are not always suitable for the production of secondary metabolites [23,24].

Environmental conditions undeniably play an important role in the production of mycotoxins [25]. The conditions in tropical and subtropical countries are particularly important. They are hot and humid, promoting the spread of fungi that release mycotoxins, leading to unprecedented contamination of food and feed. There is little information about losses related to mycotoxin contamination in tropical and subtropical countries [26], despite their prevalence in food products, due to the favorable conditions for their development $[26,27]$.

Since higher temperatures are more conducive to the growth of mold fungi, it is important to constantly monitor climate changes. Climate change is expected to have a meaningful impact on the safety of essential commodities related to the food industry. A key element of this influence is contamination of crops by mold fungi and their secondary metabolites. The impact of climate change on mycotoxigenic fungi requires investigating the effects of the interaction between elevated $\mathrm{CO}_{2}$ levels, temperature rise, and drought on the growth and mycotoxin production by key species of mold fungi found in grains and nuts. Mycotoxin-producing fungi may acclimatize to climate change factors, which may 
exacerbate mycotoxin-induced diseases and aggravate the infection of basic raw materials, e.g., cereals [28]. Currently, researchers are helping to identify regions where the maximum impact in terms of mycotoxigenic fungus contamination and with primary crop toxins may occur, however, this is hampered by the lack of reliable data on the impact of the influencing factors of climate change [28].

This is extremely important due to the fact that cereal grains are one of the most important sources of food for animals and humans. Due to the increase in the global population, there is a growing need to increase yields and minimize the risk of losing agricultural crops, mainly cereals. Generally, the harvested grains are stored for a certain period of time to ensure continuity of supplies throughout the year. Therefore, during storage, the economic losses caused by the deterioration of the quantity and quality of the grain can become very significant. Loss of grain is usually caused by deterioration in grain quality due to fungal contamination, which can occur both before harvest and during storage. Harmful fungi can be classified by their dominance at various stages of growth and harvesting of crops, influenced by environmental factors such as water activity $\left(a_{w}\right)$ and ecophysiological requirements [28]. Optimum conditions for mycotoxin production are shown in Table 1 [29].

Table 1. Optimum temperatures for mycotoxin production. Adapted from [29].

\begin{tabular}{ccc}
\hline Mycotoxin & Temperature $\left({ }^{\circ} \mathbf{C}\right)$ & Water Activity $\left(\mathbf{a}_{\mathbf{w}}\right)$ \\
\hline Aflatoxins & 33 & 0.99 \\
Ochratoxin & $25-30$ & 0.98 \\
Fumonosin & $15-30$ & $0.9-0.995$ \\
Zearalenone & 25 & 0.96 \\
Deoxynivalenol & $26-30$ & 0.995 \\
\hline
\end{tabular}

In the case of cereals, the essential species of mold fungus are of the genera Aspergillus and Penicillium, which can produce secondary metabolites harmful to animals and humans. The type and condition of the grain, environment, and biological factors may also influence the occurrence and dominance of mycotoxigenic fungi in the stored grain. The main environmental factors that affect cereal fungi and mycotoxins are temperature and $\mathrm{a}_{\mathrm{w}}$ [30]. Before harvest (Figure 2), hygrophilous fungi species dominate, and they usually disappear after a few months of storage. After harvest, these fungi species are replaced by mesophilic fungi species that persist during storage. Xerophilic fungi species are the dominant species present under storage conditions when the water activity drops beyond the growth limits for hydrophilic and mesophilic fungi species. The most xerotolerant group of fungi is the genus Aspergillus, followed by the genus Penicillium [31].

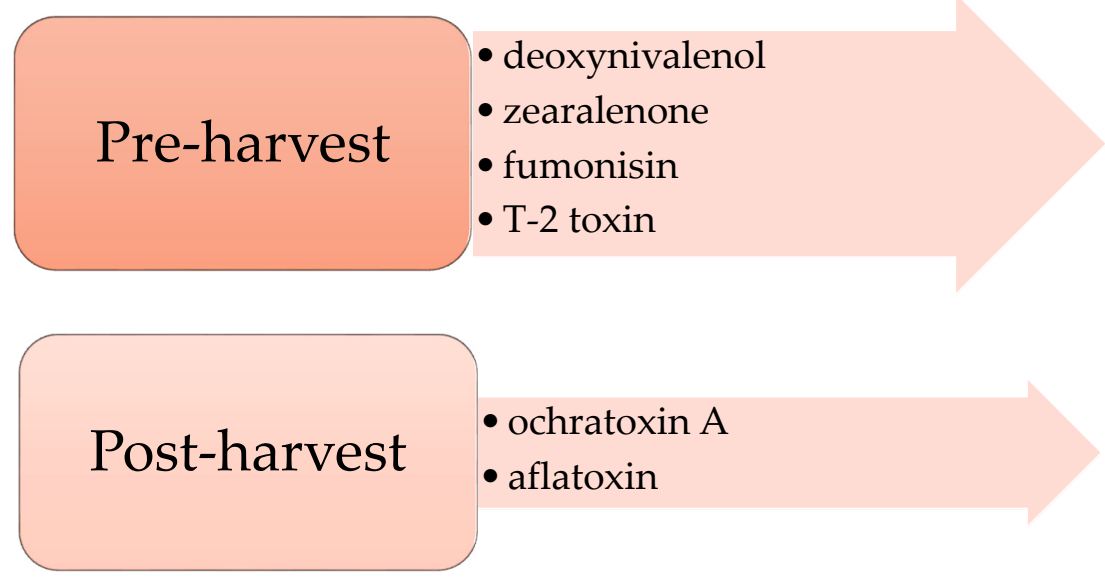

Figure 2. Mycotoxins that most often contaminate cereals pre-harvest and post-harvest. Based on $[32,33]$. 
One of the most susceptible cereals to contamination with mold fungi and mycotoxins is maize. In research [34], a comprehensive study was carried out throughout the maize production cycle to detect when contamination by mycotoxin-producing fungi occurs and how it relates to the presence of mycotoxins in stored maize. The results indicated that Aspergillus flavus and Fusarium species are able to colonize earlier in the production cycle. The presence of mycotoxins depends primarily on environmental conditions that favor contamination with mold fungi [35].

In order to prevent the development of mycotoxins and their producing fungi, a number of natural, chemical, physical, and biological methods are distinguished.

\subsection{Natural Methods}

Currently, natural methods of preventing mycotoxins are becoming more and more popular. Therefore, the use of specific agronomic practices can play a key role in minimizing levels of mycotoxin contamination by controlling mycotoxin biosynthesis as well as mold contamination and growth during plant cultivation [36]. In the case of maize, which is an essential grain used in the industry, specific agricultural practices are in place to reduce the risk of mycotoxin contamination. Among them, the use of early sowing is one of the best practices. There are studies that show that in order to reduce the risk of fumonisin contamination there is a clear need for early sowing $[37,38]$, and these are the main mycotoxins commonly detected in maize grain in temperate climates. Delaying the time of sowing corn kernels may increase the risk of contamination not only with fumonisins but also with deoxynivalenol and aflatoxin $[37,39]$.

Selecting the optimal sowing time for each region is likely to be the best technique for controlling maize contamination with major mycotoxins. However, to date, approximately 400 different mycotoxins have been identified in many plants and products, several of which have been identified in maize [40]. Some mycotoxins have been identified as emerging [41] and have not yet received detailed scientific attention. The European Food Safety Authority (EFSA) needs data on the occurrence of these metabolites in cereals to assess the exposure risk of the European population and to perform a risk assessment [39]. There is also great interest in the effect of Good Agricultural Practices (GAPs), which are commonly used in the control of fumonisin contamination in maize and in the control of contamination by other mycotoxins that arise. In this way, it will be possible to create field programs that will be able to minimize the overall risk of maize grains. As emerging mycotoxins may be produced by other Fusarium species ecologically different to fumonisin producers, as well as by other species of fungi, detailed knowledge of the environmental and agronomic conditions favorable to their occurrence is essential [39].

Strategies to prevent contamination of pre-harvest crop mycotoxins include, in addition to GAP, Good Manufacturing Practices (GMP), which ensure appropriate environmental factors, and favorable storage practices [42]. Generally, GAPs include [43,44]:

- implementation of a crop rotation program;

- use of registered insecticides, fungicides, and herbicides to control insect damage and fungal infections;

- weed removal;

- $\quad$ proper seedbed treatment;

- $\quad$ soil analysis to determine the need to add fertilizers.

In addition, the use of biological control agents such as antagonistic fungi are an important pre-harvest strategy to prevent mycotoxin contamination of cereals, grapes, and apples [45]. In terms of favorable storage practices, temperature, humidity, and storage humidity are key factors for mold growth and mycotoxin production $[42,46]$.

According to [47], to prevent mycotoxin contamination, the five keys to mycotoxin prevention and control in grains must be used:

1. Maintaining the vigor and health of plants-a strong and healthy plant is able to fight pests and diseases, including fungi. 
2. Reduction of toxic fungal populations in growing plants and during storage-although fungi are ubiquitous, some environments have a larger population than others, with a consequential greater risk of mycotoxin contamination. Avoiding and limiting fungal populations reduces the risk of mycotoxin contamination.

3. Rapidly reducing grain moisture content and avoiding rehydration-high grain moisture levels in harvested grains and high ambient air humidity are critical factors for fungal proliferation and mycotoxin contamination.

4. Protective husk/scales or pericarp-The outer seed/kernel structures, such as the husk/pods and seed coat, provide the first line of defense against fungal contamination.

5. Purification and removal of high-risk components of mycotoxins (fungus/disease, immature and damaged fractions, dirt, and debris). Mycotoxins are concentrated in moldy, broken, insect-damaged, wrinkled, and immature grains and dirt/debris [47].

\subsection{Chemical and Physical Methods}

It has been shown that, after harvesting, secondary metabolites can be eliminated by natural methods such as radiation therapy, thermal insulation, and low-temperature plasma [48], as well as by chemical methods such as oxidation, hydrolysis, reduction and absorption, and biological methods using biological agents [49]. However, chemical and physical detoxification methods have many limitations; they cause loss of nutrients, are time consuming and ineffective, and require expensive equipment. Physical mycotoxin disposal practices include classifying, sorting, and disposing of obviously contaminated parts [50]. Physical methods also include drying, washing, cleaning, sorting, grinding, cooking, baking, irradiating, extrusion, microwave heating and peeling [46]. Chemical methods include treating seeds with ammonia, application of chitosan, ozonation [51-53].

\subsection{Biological Methods}

Biological methods turn out to be more specialized, more effective, and more environmentally friendly [54]. The methods of biological control of mycotoxin contamination include, for example, the use of bacteria. Some of them have a binding capacity mycotoxin in food or liquids [55]. Flavobacterium aurantiacum B-184 was shown to be the only bacterium, among over 1000 tested for possible aflatoxin degradation, capable of irreversibly removing aflatoxin from solutions. Yeast also represents a biological strategy to combat mycotoxins, as it produces antimicrobial compounds with beneficial effects on animals and humans; on the other hand, they can grow rapidly on many media in bioreactors. Another method is fermentation [56], which is a fairly inexpensive method of mycotoxin disinfection and can be used both to improve food ingredients and to reduce or even eliminate secondary metabolites [57].

\subsection{Novel Methods}

Novel detoxification strategies include the use of, inter alia, nanoparticles and plant extracts [46].

Plants and their biologically active substances are considered to be safe and friendly sources of substances that can be used to control fungi in food and feed [58]. They are considered more affordable, and they also provide a synergistic approach as protective measures against fungal/mycotoxin contamination and have the ability to stimulate the pathways that trigger natural defense systems in plant tissues $[59,60]$. In addition, they have antimicrobial, antioxidant, and anti-carcinogenic properties. They are also capable of reducing the toxic and genotoxic effects of mycotoxins [61]. Recent studies are underway on the possible use of herbal agents as biofungicides and nutraceuticals to inhibit fungal growth and mycotoxin contamination in food and feed [62-64]. For example, the antifungal and antimicotoxigenic effects of wild stevia extracts against $A$. flavus, A. ochraceus, A. niger, and $F$. moniliforme have been demonstrated [65]. Moreover, essential oils have been found to be effective in modulating the growth of mycotoxigenic fungi such as A. favus, A. 
oryzae, A. niger, Alternaria alternata, F. moniliforme, F. graminearum, Penicillium citrinum, and P. viridicatum and related mycotoxins $[61,65,66]$.

In terms of mycotoxin reduction, novel approaches have shown that fumonisin contamination can be reduced by detoxifying a microbial enzyme. In study [67], the bacterium Serratia marcescens 329-2 was identified from maize with high activity towards the reduction of $\mathrm{FB}_{1}$. A hydrolase and a transferase with increased expression in bacterial cells were also found, which may indicate a potential for the development of $\mathrm{FB}_{1}$-reducing enzymes [67]. Results of these studies showed that the hydrolase and transferase enzymes, which can cooperate in the degradation of fumonisin, showed high expression compared to their levels in the control samples. These studies showed that Serratia marcescens 329-2 is a novel bacterium with the potential to reduce $\mathrm{FB}_{1}$, and the production of $\mathrm{FB}_{1}$-reducing enzymes should be further investigated [67].

Other studies—conducted towards the degradation of aflatoxin [68]—have shown that microbial degradation is an effective and attractive method of eliminating aflatoxin $\mathrm{B}_{1}\left(\mathrm{AFB}_{1}\right)$. In this study [68], Aspergillus niger RAF106 was able to efficiently degrade $\mathrm{AFB}_{1}$. The ability of intracellular enzymes or proteins with excellent thermotolerance to degrade $\mathrm{AFB}_{1}$ to metabolites with low or no mutagenicity was verified. In addition, genomic sequence analysis showed that the fungus was considered safe due to the lack of virulence genes and gene clusters for mycotoxin synthesis. These results indicate that A. niger RAF106 and its intracellular enzymes or proteins have promising potential for commercial use in food and feed processing and in the industry for the detoxification of $\mathrm{AFB}_{1}[68]$.

\section{Detection}

The detection of mycotoxins is extremely important due to their toxicity [69]. Maximum permissible levels of mycotoxins are regulated worldwide by relevant legal acts [70], and the monitoring of their presence in certain goods is obligatory to ensure food safety and to protect the health of potential consumers [70,71]. Analytical methods for the detection of secondary metabolites of mold fungi include immunochemical techniques [72], which are mainly used for routine inspections and rapid on-site detection, and chromatographybased techniques that provide sensitive, accurate, and selective determinations of known species of mycotoxins [70].

Methods of detecting mycotoxins are very important due to the enormous health risk that mycotoxins pose. However, real-time detection has a high background and a low signal-to-noise ratio, so it is difficult to meet fast, accurate, and convenient food quality control requirements. In the study [73], a quantitative fluorescence image analysis based on microspheres encoded in multicolor nanocrystals (UCN) for the detection of ochratoxin A and zearalenone was constructed. The results showed that this novel detection platform provides feasible and reliable measurements of the fluorescence image by this method. Researchers predict that this UCN coding strategy will be useful for quickly, accurately, and conveniently testing many food contaminants to ensure food safety [73].

In the study [74], a new aptamer microarray method on the $\mathrm{TiO}_{2}$-porous silicon (PSi) surface was developed to simultaneously screen multiplex secondary metabolites. The newly developed method shows good recovery rates and specificity. This method could provide a simple, sensitive, and cost-effective platform for the simultaneous screening of multiplex mycotoxins and could easily be extended to another aptamer-based protocol.

In addition to classical enzyme immunoassays (ELISA), in recent years, biosensors for the analysis of mycotoxins in food have been developed, which are characterized by simplicity, reproducibility, accuracy, fast analysis, and low cost. Nanomaterials have been incorporated into biosensors to obtain better analytical performance and reduce production costs [75]. One of the best-studied nanomaterials are gold nanoparticles (AuNPs), which can be used as an immobilization carrier, signal enhancer, mediator, and mimetic enzyme marker [75]. 
Technological progress is conducive to the development of sensitive methods for the detection of specific mycotoxins. This is the case with detection of $\mathrm{AFM}_{1}$ in milk. In study [76], a monospecific polyclonal antibody (IgGMS-M1) was produced that bound to $\mathrm{AFM}_{1}$ with high avidity. In the next step, the antibody was coupled with the invertase enzyme obtained from the yeast Saccharomyces cerevisiae. After incubating the invertaseconjugated anti-AFM $\mathrm{Am}_{1}$ antibody with the milk containing $\mathrm{AFM}_{1}$, the amount of glucose produced was measured with a glucometer and correlated with the amount of $\mathrm{AFM}_{1}$ present in the milk. The obtained results showed that the test was very sensitive and could be easily adapted as a portable instrument for $\mathrm{AFM}_{1}$ measurements on site, outside the laboratory [76,77].

The research [78] developed a screening method for the analysis of mycotoxins in spices and cereal products using ultra-high performance liquid chromatography coupled with tandem mass spectrometry (UHPLC-MS / MS). It has been found that the developed method is a good solution for use in screening tests and routine analyses to monitor the mycotoxin content in food in accordance with European regulations. However, further research is needed to increase the number of mycotoxins analyzed and the group of goods analyzed with the same method [78].

\section{Impact on Animal Health}

Contamination of animal food with mycotoxins is still common, despite great efforts to prevent it. Animal feed can be contaminated with low levels of several mycotoxins simultaneously, especially those produced by fungi of the genera Aspergillus and Fusarium species (aflatoxin $B_{1}$, ochratoxin $A$, zearalenone, deoxynivalenol, and fumonisin $B_{1}$ ) $[79,80]$.

Diseases caused by secondary metabolites are called mycotoxicoses [81]. The degree of toxicity that these compounds exert on the animal's body depends primarily on the type of mycotoxin, amount, duration of exposure, overall health of the animal, sex, age, race, and other factors [82-85].

Mycotoxins are one of the main pollutants in the diet of animals, and their presence may harm the health of not only farm animals but also companion animals [86,87]. Intensive rearing of poultry and pigs may pose a risk to animal health and production due to the high consumption of grains and oilseeds, which are more likely to contain mycotoxins $[87,88]$.

Mycotoxins affect various organ systems. These include the digestive system, the liver, and the immune system. Additionally, they generally reduce productivity. The presence of even one type of mycotoxin can be harmful to animals, and the presence of more than one type can be more toxic due to their synergism. The toxic effects of mycotoxins lead to oxidative stress (OS) and the formation of free radicals $[89,90]$. The increased number of free radicals as a result of the malfunctioning of the antioxidant system leads to damage to the structure of DNA, proteins, and lipids [91].

In order to prevent mycotoxicosis in farm animals, the European Commission (EC) has issued regulations on additives for use in animal nutrition [92]. The category of technological feed additives defines a new group of feed additives as "substances to reduce the contamination of feed by mycotoxins: substances that can inhibit or reduce the absorption, promote the excretion of mycotoxins or modify the way they act" [92]. The ubiquity of mycotoxins in feed and its ingredients is of great concern, as they represent a major risk factor for both animal performance and human health. One of the strategies to reduce the presence of mycotoxins in feed is the introduction of mineral adsorbents into the feed. They are a feed additive used to prevent the formation of lumps-they are an anti-caking agent. At the same time, their task is to bind and reduce the level of mycotoxins [93]. The safety of these measures is a matter of dispute. Studies on the use of mineral adsorbents are either contradictory or lack some degree of accuracy in their assessments. These agents have the ability to enter the body through a variety of routes, including inhalation, ingestion, and skin penetration [94]. It has also been suggested that accessory minerals such as metal oxides, including $\mathrm{TiO}_{2}$ and $\mathrm{ZnO}$, which are contained in clays, may be responsible for induced toxicity in various cell lines. The degree of 
toxicity depends on the size, shape, surface properties, and chemical composition of the adsorbent [95].

It has been shown that both natural and modified adsorbents can induce cytotoxic effects such as decreased cell viability, oxidative stress, apoptosis, and DNA damage. They also have the ability to bind micronutrients and vitamins present in feed, which leads to reduced digestibility, immunosuppression, and low productivity of livestock. These agents can also interact with veterinary drugs, leading to a reduction or increase in drug absorption and to potential treatment failure and higher levels of antibiotic residues in food of animal origin. Mineral adsorbents may also contain various amounts of auxiliary minerals, heavy metals (lead, copper, cadmium), dioxins, and trace elements, the presence of which leads to negative health consequences [81]. The remaining selected dietary supplements preventing mycotoxins are presented in Table 2.

Table 2. Food additives for the diet against mycotoxins. Based on [96-101].

\begin{tabular}{|c|c|}
\hline Item & Activity/Mechanism \\
\hline $\begin{array}{l}\text { Antioxidants both } \\
\text { natural (vitamins, provitamins, carotenoids, chlorophyll and its } \\
\text { derivatives, phenolics, and selenium) and synthetic (butylated } \\
\text { hydroxyanisole and butylated hydroxytoluene) }\end{array}$ & Prevention of damage to cell membranes \\
\hline Selenium (Se) & $\begin{array}{l}\text { Limitation of the toxic activity of mycotoxins in vitro and } \\
\text { in vivo, prevention against the carcinogenic effect of aflatoxins }\end{array}$ \\
\hline Polyunsaturated fatty acids (PUFA), concerns mainly: & Reduction of immunoglobulin A induced nephropathy \\
\hline Eicosapentaenoic acid (EPA) & $\begin{array}{l}\text { Inhibition of deoxynivalenol induced development of IgA } \\
\text { nephropathy }\end{array}$ \\
\hline Docosahexaenoic acid (DHA) & $\begin{array}{c}\text { Attenuation of the deoxynivalenol-induced pro-inflammatory } \\
\text { response }\end{array}$ \\
\hline EPA and DHA & $\begin{array}{c}\text { Reduction of deoxynivalenol-induced interleukin- } 6 \text { production, } \\
\text { alleviating kidney inflammation }\end{array}$ \\
\hline
\end{tabular}

As mentioned earlier, grains and their by-products are generally the main ingredients of feed. Food processing influences the concentration of secondary metabolites of mold fungi. The impact of mycotoxins is variable and depends on their chemical structure, quantity, and exposure time. This is a very important problem in the processing of cereals, due to the fact that the presence of mycotoxins has both health and economic effects. The presence of mold fungi in the pet food and feed affects its palatability and nutritional value. What is more, it creates the risk of poisoning [102].

\subsection{Farm Animals}

Due to the consumption of feed containing mainly cereals, poultry and pigs are at the highest risk of ingesting mycotoxins. In the case of horses, it was reported that the longterm feeding of feed with even acceptable levels of mycotoxins significantly decreased the content of testosterone and increased the content of estradiol in the blood of stallions [103].

In general, monogastric and younger animals are more sensitive to mycotoxins than ruminants and older animals [104]. The toxic effects of mycotoxins vary depending on their chemical structure, concentration, exposure time, species, sex, age, and sensitivity of the infected animal. It has been shown that the consumption of mycotoxins may deteriorate the health condition and reduce the productivity of animals. Diseases caused by mycotoxins reduce animal production. In addition, they generate greater morbidity and mortality [104]. Chronic exposure to low concentrations of secondary metabolites of mold fungi may cause production losses and increase the risk and incidence of other diseases [104].

In addition to its effects on animal health, some mycotoxins may be excreted in milk, causing food safety problems and a risk to human health. For example, it has been shown that aflatoxin is transferred into the milk of lactating cattle with serious problems. Among $\mathrm{AFs}, \mathrm{AFB}_{1}$ is the prevalent and most toxic. In the liver, it is transformed into $\mathrm{AFM}_{1}$, which is then excreted into the milk of lactating mammals, including dairy animals. $\mathrm{AFM}_{1}$ has 
been shown to be the cause of both acute and chronic toxicoses. The presence of $\mathrm{AFM}_{1}$ in milk and dairy products represents a worldwide concern since even small amounts of this metabolite may be of importance as long-term exposure is concerned [105]. This is very important for human health around the world because aflatoxin is classified as a carcinogen, and children, the main consumers of milk, are more susceptible to its harmful effects [106].

Minor transfer of fumonisin, zearalenone, ochratoxin A, and deoxynivalenol has been reported, but the health effects of these are unknown. Transfer studies and studies of mycotoxins in milk have not been widely conducted, except in the aflatoxin $\mathrm{M}_{1}$ studies. Ruminants have been shown to be generally less exposed to the adverse effects of mycotoxins because the rumen microflora partially breaks them down. When ingested by ruminants, some of the ingested aflatoxin $B_{1}$ is broken down in the rumen. As early as 1984, Kiessling et al. [107] suggested that the type of rumen microflora will determine the level of degradation and is dependent on species, age, sex, and race. Upadhaya et al. [108] also reported that aflatoxin $\mathrm{B}_{1}$ was degraded by $14 \%$ in cattle compared to $25 \%$ in goats, with the type of feed also determining the level of degradation.

The presence of mycotoxins in goat's and cow's milk may be due to poor handling and storage practices, but grazed goats are more likely to take mycotoxins when feeding in human waste landfills, where mold and mycotoxin contamination are common. In [109] study, $\mathrm{AFM}_{1}$ was the dominant aflatoxin detected in milk samples. Interestingly, all cow's milk samples were contaminated with $\mathrm{AFM}_{1}$, while in the case of goat's milk it was $49 \%$.

Pigs are one of the most sensitive species to mycotoxins. Female pigs are particularly susceptible to deoxynivalenol and zearalenone [110]. Zearalenone has been shown to negatively affect the reproductive function of pigs [111]. The estrogenic effects of zearalenone on gilts or sows include, but are not limited to, uterine edema, ovarian cyst formation, increased follicle maturation, and an increase in stillborn fetuses. They also showed degeneration of the embryonic epithelium and altered sperm formation in boars, as a result of the action of zearalenone. Reproductive disorders (e.g., ovarian and uterine atrophy, ovarian degeneration, and endometrial gland dysfunction) have also been reported when sows have been exposed to feed contaminated with T-2 toxin from the trichothecene group. Symptoms of prenatal T-2 poisoning have also been observed in suckling piglets (e.g., endometrial glandular dysfunction, gastrointestinal edema, and hematopoiesis leading to death) $[111,112]$.

It has been shown that pigs that were chronically exposed to a fodder contaminated with deoxynivalenol showed increased expression of interleukin 8 and glutathione peroxidase. Deoxynivalenol leads to disturbances in mRNA translation, which affects cell proliferation and immune response, and it reduces the food intake and growth of pigs. Importantly, the presence of deoxynivalenol also impairs gut health by reducing the proliferation of enterocytes and the intestinal surface, resulting in impaired weight gain [113].

In the case of poultry, the negative effects of mycotoxins result in a decrease in feed consumption, insufficient feed conversion, and a decrease in the growth rate of broiler chickens in the production cycle [114].

Poultry have been shown to be more tolerant to ZEN toxicity. Reported levels of ZEN in poultry feed may not have acute effects on poultry health and performance in isolation, however, chronic exposure may have effects on fertility. In poultry, high levels of DON have been found to affect growth rate and feed efficiency and to increase susceptibility to infectious diseases, such as necrotizing enterocolitis. Moreover, levels below the EU guideline level may negatively affect metabolic, immune, and physiological aspects in these farm animals [115]. Research [116] confirms the fact that feed intake is lower in hens that consume feed contaminated with mycotoxins. In these studies, the hens that consumed the mycotoxins had lower resistance and sap thickness. There were also fluctuations in liver enzyme levels in individuals consuming mycotoxins, and the cumulative effect increased the activity of alanine aminotransferase. The conclusion is that, overall, the consumption of mycotoxins deteriorated the performance and quality of hen eggs. However, the negative 
effects caused by the action of mycotoxins can be minimized by the use of S. cerevisiae lysate and organic acids in the diet [116]. Study results [117] suggest that local mycotoxin binding ameliorates the toxicopathological effects of $\mathrm{AFB}_{1}$ in terms of mortality, feed consumption, body weight, and visceral organ changes. The results of these studies showed that $\mathrm{AFB}_{1}$ poisoning leads to weight loss and that feed consumption is dose dependent. The use of a topical mycotoxin binder can be an economical solution to the problem of aflatoxicosis, making poultry production more profitable.

\subsection{Aquaculture Animals}

The ingredients of fish feed are mainly fish meal, wheat, soy products, and corn. Research [118] shows that fish are at high risk of toxin contamination if low-quality feed ingredients are selected for feed production. Moreover, when several mycotoxins are present in the feed, the effect may be synergistic. Depending on the species, individual sensitivity, and age, mycotoxins may cause different symptoms in fish. It has also been shown that cold-water fish are more sensitive to the effects of mycotoxins compared to warm-water fish species [119]. In fish, when poisoned with aflatoxins, retarded growth, liver damage, immunosuppression, and pale gills may occur [120,121]. The presence of zearalenone in fish feed results in immunotoxic, genotoxic, hepatotoxic, and cytotoxic effects. Moreover, it causes damage to kidney tissue [122]. Deoxynivalenol affects growth retardation and reduces feed consumption. Ochratoxin A causes deformation of fish, delays growth, and increases embryo creaminess, which is related to the increased production of oxidative stress [123]. Therefore, it is important to monitor the safety of fish feed, and if mycotoxins are found in a given feed, they should be withdrawn from the market.

\subsection{Companion Animals}

In the case of companion animals, as early as 1952 the consumption of moldy food was linked to cases of hepatitis in dogs. The causative agent of liver disorders has been identified as aflatoxin $B_{1}$ [111]. A significant problem for the health of companion animals is deoxynivalenol, present in maize even after its processing, which is why it is included in feeds, the main component of which are cereals [124]. Due to variable toxic reactions to mycotoxins, limits on the maximum safe levels of mycotoxins have been established in the European Union [125]. In cats, the trichothecene T-2 mycotoxin has been shown to cause hypovolemia and death. Small amounts of T-2 in cats have been shown to lower white blood cell counts [111]. As with other species, the kidneys are the major target organ of ochratoxin A in dogs and cats. Symptoms of poisoning with this toxin in dogs include anorexia, excessive thirst, polyuria, restlessness, weakness, and death Post-mortem examination revealed degeneration of the epithelium (proximal tubules), muco-hemorrhagic enteritis (caecum, colon, and rectum), and necrosis of lymphoid tissues (spleen, tonsils, thymus, and peripheral lymph nodes) [111].

Due to intense globalization, pet food can be commercialized all over the world, and the issue of dry dog food safety has become a subject of widespread international concern. The study [126] assessed the safety of cheap and expensive dry feed and the exposure of dogs to mycotoxins through naturally contaminated feed. Although the food samples were often contaminated with aflatoxins, fumonisins, and zearalenone, the estimated daily intake values were low, even with the low-cost foods. However, it cannot be ruled out that some feed samples may have a negative effect on the health and performance of the animals, taking into account the mono-diet feeding of commercial feed, low levels of contamination with multiple mycotoxins, and interactions between mycotoxins. Other studies that aimed to analyze the presence of the most common mycotoxins in commercial dry dog food have shown that all common mycotoxins can be found in the samples. In addition, only one sample was found free from mycotoxin contamination. All other samples were contaminated with at least three different types of mycotoxins. In addition, it is worth noting that the concentration of aflatoxin $B_{1}$ in all samples exceeded the maximum limits established by the European Union [127]. Moreover, studies [128] showed mycotoxin 
contamination in $99 \%$ of pet food samples, where the most commonly detected mycotoxins were those produced by fungi of the genus Fusarium. All positive samples showed the coexistence of mycotoxins with up to 16 analytes present per sample. Retrospective screening initially identified fungal metabolites such as cyclopiazonic acid, paspalitrem A, fusaric acid, and macrosporin, which are the most frequently detected analytes.

For dogs, the tremorgenic mycotoxin penitrem A is also a threat. Penitrem A is mainly produced by fungal species belonging to the genus Penicillium as a secondary metabolite in moldy food and feed. Dogs can be exposed to penitrem A when they ingest rotten food scraps or fruit that has fallen from trees. Penitrem A is a lipophilic toxin that penetrates the blood-brain barrier, reaches neuroreceptors, and damages the mechanisms of neurotransmitter release in the central and peripheral nervous system. Typical symptoms of penitrem A poisoning are continuous or periodic tremors which, depending on the dose absorbed, may be transient, persistent, or fatal. Currently, no information is available on the biotransformation and toxicokinetics of penitrem A in dogs [129]. There is a known case of a dog that vomited after eating walnuts that had been lying on the ground for 5 months. The dog then developed tremors, ataxia, increased salivation, and hyperalgesia. A walnut shell was visible in the vomit. Due to the sudden onset of tremors, the lack of exposure to other toxins causing seizures, and the evidence of nut consumption, the initial diagnosis was tremorgenic mycotoxicosis. The dog was treated symptomatically and recovered completely. Tremorgenic mycotoxins were detected within walnuts collected from the dog's environment [130].

Another risk is patulin (PAT). It is mainly produced by Penicillium and Aspergillus and is found in apples, pears, grapes, sweet peppers, and carrots [131,132]. PAT is toxic to both humans and animals, even in small doses [133]. After entering the body, PAT concentrates in well-supplied organs, such as the liver and kidneys. Its toxicity manifests itself mainly in reaction with compounds such as glutathione and thioglycolate [133].

Rodents have been used for many years for modeling the effects of mycotoxins on humans, especially with regard to the carcinogenic potential of aflatoxin. Unlike rats, mice are generally resistant to the hepatocarcinogenic effects of aflatoxin $B_{1}$ [134]. In rats, aflatoxins lead to the formation of lung tumors and liver tumors [135]. The negative effect of trichothecenes on rats has been known for decades, and, as a result, the rat has been widely used as a model for testing the toxicity of trichothecenes [111]. Longterm oral administration of T-2 toxin has been shown to reduce feed consumption in a dose-dependent manner and lead to gastric ulcers, thymic depression, decreased nutrient and lipid absorption, and decreased metabolism, leading to symptoms such as elevated levels of triglycerides, free cholesterol, total phospholipids, and phosphatidylcholine [136]. Symptoms of acute T-2 toxicity in rats include lethargy, decreased feed consumption, decreased body temperature, a three-fold increase in white blood cells and lymphocytes, hypertension, and finally tachycardia preceding hypotension and death [111].

Currently, in the nutrition of animals, especially dogs, there is a growing tendency of interest in food made from insects. Insects seem to be a suitable alternative to livestock production. However, they can grow on a variety of media that may be naturally contaminated with mycotoxins. Research on the safety of insects as feed ingredients is mandatory for the feed industry. Studies have been conducted [137] assessing the uptake and/or excretion of mycotoxins in two different insect species, Alphitobius diaperinus and Hermetia illucens, grown on naturally contaminated wheat and/or corn (deoxynivalenol, fumonisin $B_{1}$, fumonisin $B_{2}$, and zearalenone). It was shown that Hermetia illucens larvae did not contain mycotoxins, while small amounts of deoxynivalenol and fumonisin $B_{1}$ were detected in Alphitobius diaperinus larvae. In addition, it was shown that the larvae of both species metabolized mycotoxins in unknown forms, accumulating them in the body or excreting them with feces. The results indicated that more research is needed in this direction due to the future use of insects as food [138]. 


\section{Conclusions}

The numerous examples in the literature illustrate that the mycotoxins are compounds that we are unable to completely eliminate from the environment. They have a detrimental effect on the health of animals, which is also a threat to humans. This is due to the fact that mycotoxins have the ability to accumulate in the tissues of animals or may pass into milk, which poses a risk of their consumption by humans. Their presence leads to economic losses, and it causes negative health effects in animals and, in extreme cases, leads to their death. Despite the known methods (natural, chemical, physical, biological) of prevention, the topic of threats related to their presence is still topical. In the long term, their levels should still be monitored, and the presence of molds that produce them should be detected as early as possible. Maximum permissible levels of mycotoxins are regulated worldwide by relevant legal acts, and the monitoring of their presence in certain goods is obligatory to ensure food safety and to protect the health of potential consumers.

Author Contributions: Conceptualization, J.K.-P., W.B.; software, J.K.-P., W.B.; validation, J.K.-P., W.B.; investigation, J.K.-P., W.B.; resources, J.K.-P., W.B.; data curation, J.K.-P., W.B.; writing—original draft preparation, J.K.-P., W.B.; writing-review and editing, J.K.-P., W.B.; visualization, J.K.-P.; supervision, J.K.-P., W.B. All authors have read and agreed to the published version of the manuscript.

Funding: This research received no external funding.

Institutional Review Board Statement: Not applicable.

Informed Consent Statement: Not applicable.

Conflicts of Interest: The authors declare no conflict of interest.

\section{References}

1. Peivasteh-Roudsari, L.; Pirhadi, M.; Shahbazi, R.; Eghbaljoo Gharehgheshlaghi, H. Mycotoxins: Impact on health and strategies for prevention and detoxification in the food chain. Food Rev. Int. 2021, 33, 1-32. [CrossRef]

2. Ülger, T.G.; Uçar, A.; Çakıroğlu, F.P.; Yilmaz, S. Genotoxic effects of mycotoxins. Toxicon 2020, 185, 104-113. [CrossRef] [PubMed]

3. Gajęcki, M.T.; Gajęcka, M.; Zielonka, Ł. The presence of mycotoxins in feed and their influence on animal health. Toxins 2020, 12, 663. [CrossRef]

4. Zinedine, A.; Akhdari, S. Food Safety and Climate Change: Case of Mycotoxins. In Research Anthology on Food Waste Reduction and Alternative Diets for Food and Nutrition Security; IGI Global: Hershey, PA, USA, 2019. [CrossRef]

5. Daou, R.; Joubrane, K.; Maroun, R.G.; Khabbaz, L.R.; Ismail, A.; El Khoury, A. Mycotoxins: Factors influencing production and control strategies. AIMS Agric. Food 2021, 6, 416-447. [CrossRef]

6. Pascari, X.; Ramos, A.J.; Marín, S.; Sanchís, V. Mycotoxins and beer. Impact of beer production process on mycotoxin contamination. Int. Food Res. J. 2018, 103, 121-129. [CrossRef]

7. Mohammedi-Ameur, S.; Dahmane, M.; Brera, C.; Kardjadj, M.; Ben-Mahdi, M.H. Occurrence and seasonal variation of aflatoxin M1 in raw cow milk collected from different regions of Algeria. Vet. World 2020, 13, 433-439. [CrossRef] [PubMed]

8. Nazhand, A.; Durazzo, A.; Lucarini, M.; Souto, E.B.; Santini, A. Characteristics, occurrence, detection and detoxifi-cation of aflatoxins in foods and feeds. Foods 2020, 9, 644. [CrossRef] [PubMed]

9. Muaz, K.; Riaz, M.; de Oliveira, C.A.F.; Akhtar, S.; Ali, S.W.; Nadeem, H.; Park, S.; Balasubramanian, B. Aflatoxin M1 in milk and dairy products: Global occurrence and potential decontamination strategies. Toxin Rev. 2021, 35, 1-18. [CrossRef]

10. Pleadin, J.; Staver, M.M.; Markov, K. Mycotoxins in organic and conventional cereals and cereal products grown and marketed in Croatia. Mycotoxin Res. 2017, 33, 219-227. [CrossRef]

11. Ghidini, S.; Zanardi, E.; Battaglia, A.; Varisco, G.; Ferretti, E.; Campanini, G.; Chizzolini, R. Comparison of contaminant and residue levels in organic and conventional milk and meat products from northern Italy. Food Addit. Contam. 2005, 22, 9-14. [CrossRef]

12. Díaz Nieto, C.H.; Granero, A.; Zon, M.A.; Fernández, H. Sterigmatocystin: A mycotoxin to be seriously considered. Food Chem. Toxicol. 2018, 118, 460-470. [CrossRef]

13. Dufera, L.T. Management of mycotoxin in post-harvest food chain of durable crops. FSQM 2020, 100, 12-20.

14. Rodrigues, I.; Naehrer, K. A three-year survey on the worldwide occurrence of mycotoxins in feedstuffs and feed. Toxins 2012, 4, 663-675. [CrossRef]

15. Humpf, H.U.; Rychlik, M.; Cramer, B. Modified mycotoxins: A new challenge? Food Chem. 2019, 1, 393-400. [CrossRef]

16. Freire, L.; Sant'Ana, A. Modified mycotoxins: An updated review on their formation, detection, occurrence, and toxic effects. Food Chem. Toxicol. 2018, 111, 189-205. [CrossRef] [PubMed] 
17. Karlovsky, P.; Suman, M.; Berthiller, F.; De Meester, J.; Eisenbrand, G.; Perrin, I.; Oswald, I.P.; Speijers, G.; Chiodini, A.; Recker, T.; et al. Impact of food processing and detoxification treatments on mycotoxin contamination. Mycotoxin Res. 2016, 32, 179-205. [CrossRef]

18. Taniwaki, M.H.; Pitt, J.I. Mycotoxins. In Food Microbiology: Fundamentals and Frontiers, 5th ed.; Doyle, M.P., Diez-Gonzales, F., Hill, C., Eds.; ASM Press: Washington, DC, USA, 2019; Volume 22, pp. 587-608.

19. Bhatnagar, D.; Rajasekaran, K.; Payne, G.; Brown, R.; Yu, J.; Cleveland, T. The "omics" tools: Genomics, proteomics, metabolomics and their potential for solving the aflatoxin contamination problem. World Mycotoxin J. 2008, 1, 3-12. [CrossRef]

20. Bhatnagar, D.; Rajasekaran, K.; Gilbert, M.; Cary, J.W.; Magan, N. Advances in molecular and genomic research to safeguard food and feed supply from aflatoxin contamination. World Mycotoxin J. 2018, 11, 47-72. [CrossRef]

21. Medina, A.; Schmidt-Heydt, M.; Rodríguez, A.; Parra, R.; Geisen, R.; Magan, N. Impacts of environmental stress on growth, secondary metabolite biosynthetic gene clusters and metabolite production of xerotolerant/xerophilic fungi. Curr. Genet. 2015, 61, 325-334. [CrossRef]

22. Magan, N.; Medina, A. Mycotoxins, food security and climate change: Do we know enough? Microbiol. Today 2016, 31, 143-154.

23. Medina, A.; Gilbert, M.K.; Mack, B.M.; O’Brian, G.R.; Rodríguez, A.; Bhatnagar, D.; Payne, G.; Magan, N. Interactions between water activity and temperature on the Aspergillus flavus transcriptome and aflatoxin B1 production. Int. J. Food Microbiol. 2017, 256, 36-44. [CrossRef]

24. Garcia-Cela, E.; Verheecke-Vaessen, C.; Magan, N.; Medina, A. The "-omics" contributions to the understanding of mycotoxin production under diverse environmental conditions. Curr. Opin. Food Sci. 2018, 23, 97-104. [CrossRef]

25. Navale, V.; Vamkudoth, K.R.; Ajmera, S.; Dhuri, V. Aspergillus derived mycotoxins in food and the environment: Prevalence, detection, and toxicity. Toxicol. Rep. 2021, 8, 1008-1030. [CrossRef] [PubMed]

26. Imade, F.; Ankwasa, E.M.; Geng, H.; Ullah, S.; Ahmad, T.; Wang, G.; Zhang, C.; Dada, O.; Xing, F.; Zheng, Y.; et al. Updates on food and feed mycotoxin contamination and safety in Africa with special reference to Nigeria. Mycology 2021, 12, 1-16. [CrossRef]

27. Chilaka, C.A.; De Boevre, M.; Atanda, O.O.; De Saeger, S. Quantification of fusarium mycotoxins in Nigerian traditional beers and spices using a multi-mycotoxin LC-MS/MS method. Food Control 2018, 87, 203-210. [CrossRef]

28. Medina, A.; Akbar, A.; Baazeem, A.; Rodriguez, A.; Magan, N. Climate change, food security and mycotoxins: Do we know enough? Fungal Biol. Rev. 2017, 31, 143-154. [CrossRef]

29. Milani, J.M. Ecological conditions affecting mycotoxin production in cereals. Vet. Med. 2013, 58, 405-411. [CrossRef]

30. Mannaa, M.; Kim, K.D. Influence of temperature and water activity on deleterious fungi and mycotoxin production during grain storage. Mycobiology 2017, 45, 240-254. [CrossRef]

31. Fleurat-Lessard, F. Integrated management of the risks of stored grain spoilage by seedborne fungi and contamination by storage mould mycotoxins: An update. J. Stored Prod. Res. 2017, 71, 22-40. [CrossRef]

32. Pitt, J.I.; Taniwaki, M.H.; Cole, M.B. Mycotoxin production in major crops as influenced by growing, harvesting, storage and processing, with emphasis on the achievement of Food Safety Objectives. Food Control 2013, 32, 205-215. [CrossRef]

33. Bryden, W.L. Mycotoxin contamination of the feed supply chain: Implications for animal productivity and feed security. Anim. Feed Sci. Technol. 2012, 173, 134-158. [CrossRef]

34. García-Díaz, M.; Gil-Serna, J.; Vázquez, C.; Botia, M.N.; Patiño, B. A comprehensive study on the occurrence of mycotoxins and their producing fungi during the maize production cycle in Spain. Microorganisms 2020, 8, 141. [CrossRef] [PubMed]

35. Lee, H.J.; Ryu, D. Worldwide occurrence of mycotoxins in cereals and cereal-derived food products: Public health perspectives of their co-occurrence. J. Agric. Food Chem. 2017, 65, 7034-7051. [CrossRef] [PubMed]

36. Munkvold, G.P. Cultural and genetic approaches to managing mycotoxins in maize. Annu. Rev. Phytopathol. 2003, 41, 99-116. [CrossRef]

37. Camardo Leggieri, M.; Bertuzzi, T.; Pietri, A.; Battilani, P. Mycotoxin occurence in maize produced in Northern Italy over the years 2009-2011: Focus on the role of crop related factors. Phytopathol. Medit. 2015, 54, $212-221$.

38. Parson, M.W.; Munkvold, G.P. Effects of planting date and environmental factors on Fusarium ear rot symptoms and fumonisin B1 accumulation in maize grown in six North American locations. Plant Pathol. 2012, 61, 1130-1142. [CrossRef]

39. Blandino, M.; Scarpino, V.; Giordano, D.; Sulyok, M.; Krska, R.; Vanara, F.; Reyneri, A. Impact of sowing time, hybrid and environmental conditions on the contamination of maize by emerging mycotoxins and fungal metabolites. Ital. J. Agron. 2017, 12, 928. [CrossRef]

40. Kovalsky, P.; Kos, G.; Nährer, K.; Schwab, C.; Jenkins, T.; Schatzmayr, G.; Sulyok, M.; Krska, R. Co-occurrence of regulated, masked and emerging mycotoxins and secondary metabolites in finished feed and maize-An extensive survey. Toxins 2016, 8, 363. [CrossRef]

41. Streit, E.; Schwab, C.; Sulyok, M.; Naehrer, K.; Krska, R.; Schatzmayr, G. Multi-mycotoxin screening reveals the occurrence of 139 different secondary metabolites in feed and feed ingredients. Toxins 2013, 5, 504-523. [CrossRef] [PubMed]

42. Luo, Y.; Liu, X.; Li, J. Updating techniques on controlling mycotoxins-A review. Food Control 2018, 89, 123-132. [CrossRef]

43. Adebiyi, J.A.; Kayitesi, E.; Adebo, O.A.; Changwa, R.; Njobeh, P.B. Food fermentation and mycotoxin detoxification: An African perspective. Food Control 2019, 106, 106731. [CrossRef]

44. Alberts, J.F.; Lilly, M.; Rheeder, J.P.; Burger, H.M.; Shephard, G.S.; Gelderblom, W.C.A. Technological and community-based methods to reduce mycotoxin exposure. Food Control 2017, 73, 101-109. [CrossRef] 
45. Sarrocco, S.; Mauro, A.; Battilani, P. Use of competitive filamentous fungi as an alternative approach for mycotoxin risk reductionin staple cereals: State of art and future perspectives. Toxins 2019, 11, 701. [CrossRef] [PubMed]

46. Agriopoulou, S.; Stamatelopoulou, E.; Varzakas, T. Advances in occurrence, importance, and mycotoxin control strategies: Prevention and detoxification in foods. Foods 2020, 9, 137. [CrossRef]

47. Matumba, L.; Namaumbo, S.; Ngoma, T.; Meleke, N.; De Boevre, M.; Logrieco, A.F.; De Saeger, S. Five keys to prevention and control of mycotoxins in grains: A proposal. Glob. Food Sec. 2021, 30, 100562. [CrossRef]

48. Awuchi, C.G.; Ondari, E.N.; Ogbonna, C.U.; Upadhyay, A.K.; Baran, K.; Okpala, C.O.R.; Korzeniowska, M.; Guiné, R.P.F. Mycotoxins affecting animals, foods, humans, and plants: Types, occurrence, toxicities, action mechanisms, prevention, and detoxification strategies-A revisit. Foods 2021, 10, 1279. [CrossRef] [PubMed]

49. Lyagin, I.; Efremenko, E. Enzymes for detoxification of various mycotoxins: Origins and mechanisms of catalytic action. Molecules 2019, 24, 2362. [CrossRef] [PubMed]

50. Lao, E.J. The implications and management strategies of animal feed mycotoxins. Rev. Environ. Contam. Toxicol. $2020,3,53-61$.

51. Afsah-Hejri, L.; Hajeb, P.; Ehsani, R.J. Application of ozone for degradation of mycotoxins in food. Compr. Rev. Food Sci. Food Saf. 2020, 19, 1777-1808. [CrossRef]

52. Sipos, P.; Peles, F.; Brassó, D.L. Physical and chemical methods for reduction in aflatoxin content of feed and food. Toxins 2021, 13, 204. [CrossRef]

53. Pirouz, A.; Selamat, J.; Iqbal, S.; Samsudin, N. Efficient and simultaneous chitosan-mediated removal of 11 mycotoxins from palm kernel cake. Toxins 2020, 12, 115. [CrossRef] [PubMed]

54. Wang, L.; Wu, J.; Liu, Z.; Shi, Y.; Liu, J.; Xu, X.; Hao, S.; Mu, P.; Deng, F.; Deng, Y. Aflatoxin B1 degradation and detoxification by Escherichia coli CG1061 isolated from chicken cecum. Front. Pharmacol. 2019, 9, 1-9. [CrossRef]

55. Ben Taheur, F.; Kouidhi, B.; Al Qurashi, Y.M.A.; Ben Salah-Abbès, J.; Chaieb, K. Review: Biotechnology of mycotoxins detoxification using microorganisms and enzymes. Toxicon 2019, 160, 12-22. [CrossRef] [PubMed]

56. Ademola, O.; Turna, N.S.; Liverpool-Tasie, L.S.O.; Obadina, A.; Wu, F. Mycotoxin reduction through lactic acid fermentation: Evidence from commercial ogi processors in southwest Nigeria. Food Control 2021, 121, 107620. [CrossRef]

57. Zadeike, D.; Vaitkeviciene, R.; Bartkevics, V.; Bogdanova, E.; Bartkiene, E.; Lele, V.; Juodeikiene, G.; Cernauskas, D.; Valatkeviciene, $\mathrm{Z}$. The expedient application of microbial fermentation after whole-wheat milling and fractionation to mitigate mycotoxins in wheat-based products. LWT 2021, 137, 110440. [CrossRef]

58. Adebo, O.A.; Molelekoa, T.; Makhuvele, R.; Adebiyi, J.A.; Oyedeji, A.B.; Gbashi, S.; Adefisoye, M.A.; Ogundele, O.M.; Njobeh, P.B. A review on novel non-thermal food processing techniques for mycotoxin reduction. Int. J. Food Sci. Technol. 2020, 56, 13-27. [CrossRef]

59. Alberts, J.; Rheeder, J.; Gelderblom, W.; Shephard, G.; Burger, H. Rural subsistence maize farming in South Africa: Risk assessment and intervention models for reduction of exposure to Fumonisin mycotoxins. Toxins 2019, 11, 334. [CrossRef]

60. Meng, D.; Garba, B.; Ren, Y.; Yao, M.; Xia, X.; Li, M.; Wang, Y. Antifungal activity of chitosan against Aspergillus ochraceus and its possible mechanisms of action. Int. J. Biol. Macromol. 2020, 158, 1063-1070. [CrossRef] [PubMed]

61. Powers, C.N.; Satyal, P.; Mayo, J.A.; McFeeters, H.; McFeeters, R.L. Bigger data approach to analysis of essential oils and their antifungal activity against Aspergillus niger, Candida albicans, and Cryptococcus neoformans. Molecules 2019, 24, 2868. [CrossRef]

62. Dikhoba, P.M.; Mongalo, N.I.; Elgorashi, E.E.; Makhafola, T.J. Antifungal and anti-mycotoxigenic activity of selected South African medicinal plants species. Heliyon 2019, 5, e02668. [CrossRef] [PubMed]

63. Ponzilacqua, B.; Rottinghaus, G.E.; Landers, B.R.; Oliveira, C.A.F. Effects of medicinal herb and Brazilian traditional plant extracts on in vitro mycotoxin decontamination. Food Control 2019, 100, 24-27. [CrossRef]

64. Kavitha, K.; Vijaya, N.; Krishnaveni, A.; Arthanareeswari, M.; Rajendran, S.; Al-Hashem, A.; Subramania, A. Nanomaterials for Antifungal Applications. In Nanotoxicity; Elsevier: Amsterdam, The Netherlands, 2020; pp. 385-398.

65. Makhuvele, R.; Naidu, K.; Gbashi, S.; Thipe, V.C.; Adebo, O.A.; Njobeh, P.B. The use of plant extracts and their phytochemicals for control of toxigenic fungi and mycotoxins. Heliyon 2020, 6, e05291. [CrossRef]

66. Abdel-Fattah, S.M.; Badr, A.N.; Seif, F.A.H.; Ali, S.M.; Hassan, A. Antifungal and antimycotoxigenic impact of eco-friendly extracts of wild stevia. J. Biol. Sci. 2018, 18, 488-499. [CrossRef]

67. Keawmanee, P.; Rattanakreetakul, C.; Pongpisutta, R. Microbial reduction of fumonisin B1 by the new isolate Serratia marcescens 329-2. Toxins 2021, 13, 638. [CrossRef]

68. Fang, Q.; Du, M.; Chen, J.; Liu, T.; Zheng, Y.; Liao, Z.; Zhong, Q.; Wang, L.; Fang, X.; Wang, J. Degradation and detoxification of aflatoxin B1 by tea-derived Aspergillus niger RAF106. Toxins 2020, 12, 777. [CrossRef] [PubMed]

69. Sun, J.; Li, W.; Zhu, X.; Jiao, S.; Chang, Y.; Wang, S.; Dai, S.; Xu, R.; Dou, M.; Li, G.; et al. A novel multiplex mycotoxin surface-enhanced raman spectroscopy immunoassay using functional gold nanotags on a silica photonic crystal microsphere biochip. J. Agric. Food Chem. 2021, 69, 11494-11501. [CrossRef] [PubMed]

70. Anfossi, L.; Giovannoli, C.; Baggiani, C. Mycotoxin detection. Curr. Opin. Biotechnol. 2016, 37, 120-126. [CrossRef] [PubMed]

71. Gallo, M.; Ferrara, L.; Calogero, A.; Montesano, D.; Naviglio, D. Relationships between food and diseases: What to know to ensure food safety. Int. Food Res. J. 2020, 137, 109414. [CrossRef]

72. Kizis, D.; Vichou, A.E.; Natskoulis, P.I. Recent advances in mycotoxin analysis and detection of mycotoxigenic fungi in grapes and derived products. Sustainability 2021, 13, 2537. [CrossRef] 
73. Yang, M.; Cui, M.; Wang, W. Background-free upconversion-encoded microspheres for mycotoxin detection based on a rapid visualization method. Anal. Bioanal. Chem. 2020, 412, 81-91. [CrossRef]

74. Liu, R.; Li, W.; Cai, T.; Deng, Y.; Ding, Z.; Liu, Y.; Zhu, X.; Wang, X.; Liu, J.; Liang, B.; et al. TiO 2 nanolayer-enhanced fluorescence for simultaneous multiplex mycotoxin detection by aptamer microarrays on a porous silicon surface. ACS Appl. Mater. Interfaces 2018, 10, 14447-14453. [CrossRef] [PubMed]

75. Wu, L.; Wang, M.; Weiab, D. Advances in gold nanoparticles for mycotoxin analysis. Analyst 2021, 146, 1793-1806. [CrossRef]

76. Di Giovanni, S.; Zambrini, V.; Varriale, A.; D'Auria, S. Sweet sensor for the detection of aflatoxin M1 in whole milk. ACS Omega 2019, 4, 12803-12807. [CrossRef]

77. Hamami, M.; Mars, A.; Raouafi, N. Biosensor based on antifouling PEG/Gold nanoparticles composite for sensitive detection of aflatoxin M1 in milk. Microchem. J. 2021, 165, 106102. [CrossRef]

78. Pantano, L.; La Scala, L.; Olibrio, F.; Galluzzo, F.G.; Bongiorno, C.; Buscemi, M.D.; Macaluso, A.; Vella, A. QuEChERS LC-MS/MS screening method for mycotoxin detection in cereal products and spices. Int. J. Environ. Res. Public Health 2021, $18,3774$. [CrossRef]

79. Vila-Donat, P.; Marín, S.; Sanchis, V.; Ramos, A.J. A review of the mycotoxin adsorbing agents, with an emphasis on their multi-binding capacity, for animal feed decontamination. Food Chem. Toxicol. 2018, 114, 246-259. [CrossRef]

80. Hou, L.; Zhou, X.; Gan, F.; Liu, Z.; Zhou, Y.; Qian, G.; Huang, K. Combination of selenomethionine and N-Acetylcysteine alleviates the joint toxicities of aflatoxin B1 and ochratoxin A by ERK MAPK signal pathway in porcine alveolar macrophages. J. Agric. Food Chem. 2018, 66, 5913-5923. [CrossRef]

81. Elliott, C.T.; Connolly, L.; Kolawole, O. Potential adverse effects on animal health and performance caused by the addition of mineral adsorbents to feeds to reduce mycotoxin exposure. Mycotoxin Res. 2020, 36, 115-126. [CrossRef] [PubMed]

82. Zaki, M. Mycotoxins in animals: Occurrence, effects, prevention and management. J. Toxicol. Environ. Health Sci. 2012, 4, 13-28. [CrossRef]

83. Khatoon, A. Toxico-pathological and serum biochemical alterations induced by ochratoxin a in broiler chicks and their amelioration by locally available bentonite clay. Pak. J. Agric. Sci. 2016, 53, 977-984. [CrossRef]

84. Ostry, V.; Malir, F.; Toman, J.; Grosse, Y. Mycotoxins as human carcinogens-The IARC monographs classification. Mycotoxin Res. 2016, 33, 65-73. [CrossRef] [PubMed]

85. Dellafiora, L.; Dall'Asta, C. Forthcoming challenges in mycotoxins toxicology research for safer food-A need for multi-omics approach. Toxins 2017, 9, 18. [CrossRef] [PubMed]

86. Wu, Q.H.; Wang, X.; Yang, W.; Nüssler, A.K.; Xiong, L.Y.; Kuca, K.; Dohnal, V.; Zhang, X.J.; Yuan, Z.H. Oxidative stress-mediated cytotoxicity and metabolism of T-2 toxin and deoxynivalenol in animals and humans: An update. Arch. Toxicol. 2014, 88, 1309-1326. [CrossRef] [PubMed]

87. Mavrommatis, A.; Giamouri, E.; Tavrizelou, S. Impact of mycotoxins on animals' oxidative status. Antioxidants 2021, 10, 214. [CrossRef]

88. Charoenpornsook, K.; Kavisarasai, P. Mycotoxins in animal feedstuff of Thailand. Curr. Appl. Sci. Technol. 2006, 6, 25-28.

89. Adhikari, M.; Negi, B.; Kaushik, N.; Adhikari, A.; Al-Khedairy, A.A.; Kaushik, N.K.; Choi, E.H. T-2 mycotoxin: Toxicological effects and decontamination strategies. Oncotarget 2017, 8, 33933-33952. [CrossRef]

90. Wang, X.; Wu, Q.; Wan, D.; Liu, Q.; Chen, D.; Liu, Z.; Matinez-Larranaga, M.R.; Martinez, M.A.; Anadon, A.; Yuan, Z. Fumonisins: Oxidative stress-mediated toxicity and metabolism in vivo and in vitro. Arch. Toxicol. 2016, 90, 81-101. [CrossRef]

91. Assi, M. The differential role of reactive oxygen species in early and late stages of cancer. Am. J. Physiol. Regul. Integr. Comp. Physiol. 2017, 313, R646-R653. [CrossRef] [PubMed]

92. European Commission regulation (EC). No. 386/2009 of 12 May 2009 amending Regulation (EC) No. 1831/2003 of the European Parliament and of the Council as regards the establishment of a new functional group of feed additives. Off. J. Eur. Union 2009, 118, 66. [CrossRef]

93. Kolosova, A.; Stroka, J. Evaluation of the effect of mycotoxin binders in animal feed on the analytical performance of standardised methods for the determination of mycotoxins in feed. Food Addit. Contam. Part A 2012, 29, 1959-1971. [CrossRef]

94. Maisanaba, S.; Gutiérrez-Praena, D.; Pichardo, S.; Moreno, F.; Jordá, M.; Cameán, A.; Aucejo, S.; Jos, Á. Toxic effects of a modified montmorillonite clay on the human intestinal cell line Caco-2. J. Appl. Toxicol. 2015, 34, 714-725. [CrossRef]

95. Li, P.; Wei, J.; Chiu, Y.; Su, H.; Peng, F.; Lin, J. Evaluation on cytotoxicity and genotoxicity of the exfoliated silicate nanoclay. ACS Appl. Mater. Interfaces 2010, 2, 1608-1613. [CrossRef]

96. Xiao, K.; Liu, C.; Qin, Q.; Zhang, Y.; Wang, X.; Zhang, J.; Odle, J.; Lin, X.; Hu, C.A.; Liu, Y. EPA and DHA attenuate deoxynivalenolinduced intestinal porcine epithelial cell injury and protect barrier function integrity by inhibiting necroptosis signaling pathway. FASEB J. 2020, 34, 2483-2496. [CrossRef]

97. Jia, Q.; Shi, Y.; Bennink, M.B.; Pestka, J.J. Docosahexaenoic acid and eicosapentaenoic acid, but not alpha-linolenic acid, suppress deoxynivalenol-induced experimental IgA nephropathy in mice. J. Nutr. 2004, 134, 1353-1361. [CrossRef]

98. Moriyama, T.; Kumon, S.; Kamiyama, T.; Karasawa, K.; Uchida, K.; Nitta, K. The renoprotective effects of cocosahexaenoic acid as an add-on therapy in patients receiving eicosapentaenoic acid as treatment for IgA nephropathy: A pilot uncontrolled trial. Intern. Med. 2018, 57, 173-179. [CrossRef] 
99. Zhang, Y.; Hu, B.; Wang, M.; Tong, J.; Pan, J.; Wang, N.; Gong, P.; Long, M. Selenium protects against zearalenone-induced oxidative stress and apoptosis in the mouse kidney by inhibiting endoplasmic reticulum stress. Oxidative Med. Cell. Longev. 2020, 2020, 1-10. [CrossRef] [PubMed]

100. Atroshi, F.; Rizzo, A.; Westermarck, T.; Ali-Vehmas, T. Antioxidant nutrients and mycotoxins. Toxicology 2002, 180, $151-167$. [CrossRef]

101. Bouaziz, C.; Salah, A.; Zaied, C.; Abid-Essefi, S. Natural antioxidants as efficient preventive agents against mycotoxicoses: Case of citrinin mycotoxin. BJSTR 2020, 25, 18931-18937. [CrossRef]

102. Borreani, G.; Tabacco, E.; Schmidt, R.J.; Holmes, B.J.; Muck, R.E. Silage review: Factors affecting dry matter and quality losses in silages. J. Dairy Sci. 2018, 101, 3952-3979. [CrossRef]

103. Tkachev, A.V.; Tkacheva, O.L.; Zubova, T.V.; Pleshkov, V.A.; Smolovskaya, O.V. Effect of mycotoxins on the spermatozoa and embryos of animals. Adv. Anim. Vet. Sci. 2020, 8, 47-55. [CrossRef]

104. Magnoli, A.P.; Poloni, V.L.; Cavaglieri, L. Impact of mycotoxin contamination in the animal feed industry. Curr. Opin. Food Sci. 2019, 29, 99-108. [CrossRef]

105. Giovati, L.; Magliani, W.; Ciociola, T.; Santinoli, C.; Conti, S.; Polonelli, L. AFM 1 in milk: Physical, biological, and prophylactic methods to mitigate contamination. Toxins 2015, 7, 4330-4349. [CrossRef]

106. Kemboi, D.C.; Antonissen, G.; Ochieng, P.E.; Croubels, S.; Okoth, S.; Kangethe, E.K.; Faas, J.; Lindahl, J.F.; Gathumbi, J.K. A review of the impact of mycotoxins on dairy cattle health: Challenges for food safety and dairy production in sub-saharan Africa. Toxins 2020, 12, 222. [CrossRef]

107. Kiessling, K.H.; Pettersson, H.; Sandholm, K.; Olsen, M. Metabolism of Aflatoxin, Ochratoxin, Zearalenone, and three Trichothecenes by intact rumen fluid, rumen, protozoa, and rumen bacteria. Appl. Environ. Microbiol. 1984, 47, 1070-1073. [CrossRef]

108. Upadhaya, S.D.; Sung, H.G.; Lee, C.H.; Lee, S.Y.; Kim, S.W.; Cho, K.J.; Ha, J.K. Comparative study on the Aflatoxin B1 degradation ability of rumen fluid from holstein steers and korean native goats. J. Vet. Sci. 2009, 10, 29-34. [CrossRef]

109. Akinyemi, M.O.; Braun, D.; Windisch, P.; Warth, B.; Ezekiel, C.N. Assessment of multiple mycotoxins in raw milk of three different animal species in Nigeria. Food Control 2022, 131, 108258. [CrossRef]

110. Tkaczyk, A.; Jedziniak, P. Development of a multi-mycotoxin LC-MS/MS method for the determination of biomarkers in pig urine. Mycotoxin Res. 2021, 37, 169-181. [CrossRef]

111. Zain, M.E. Impact of mycotoxins on humans and animals. J. Saudi Chem. Soc. 2011, 15, 129-144. [CrossRef]

112. Hussein, H.S.; Brasel, J.M. Toxicity, metabolism, and impact of mycotoxins on humans and animals. Toxicology 2001, 167, 101-134. [CrossRef]

113. Holanda, D.M.; Kim, S.W. Investigation of the efficacy of mycotoxin-detoxifying additive on health and growth of newly-weaned pigs under deoxynivalenol challenges. Anim. Biosci. 2021, 34, 405-416. [CrossRef] [PubMed]

114. Volkova, G.S.; Kuksova, E.V.; Serba, E.M. Prevention of mycotoxicoses in broiler chickens exposed to a mycotoxin-contaminated diet. Russ. Agricult. Sci. 2021, 47, 161-165. [CrossRef]

115. Kemboi, D.C.; Ochieng, P.E.; Antonissen, G.; Croubels, S.; Scippo, M.-L.; Okoth, S.; Kangethe, E.K.; Faas, J.; Doupovec, B.; Lindahl, J.F.; et al. Multi-mycotoxin occurrence in dairy cattle and poultry feeds and feed ingredients from Machakos Town, Kenya. Toxins 2020, 12, 762. [CrossRef] [PubMed]

116. Dazuk, V.; Boiago, M.M.; Rolim, G.; Paravisi, A.; Copetti, P.M.; Bissacotti, B.F.; Morsch, V.M.; Vedovatto, M.; Gazoni, F.L.; Matte, F.; et al. Laying hens fed mycotoxin-contaminated feed produced by Fusarium fungi (T-2 toxin and fumonisin B1) and Saccharomyces cerevisiae lysate: Impacts on poultry health, productive efficiency, and egg quality. Microb. Pathog. 2020, 149, 104517. [CrossRef]

117. Kashif, M.; Ashraf, K.; Gul, S.; Naseem, M.; Sajid, M.; Mohsin, M.; He, C.; Zubair, M.; Khan, A. Toxicopathological effects of feeding aflatoxins B1 in broilers and its ameliosration with indigenous mycotoxin binder. Ecotoxicol. Environ. Saf. 2019, 187, 109712. [CrossRef]

118. Pietsch, C. Risk assessment for mycotoxin contamination in fish feeds in Europe. Mycotoxin Res. 2020, 36, 41-62. [CrossRef] [PubMed]

119. Rajeev Raghavan, P.; Zhu, X.; Lei, W.; Han, D.; Yang, Y.; Xie, S. Low levels of aflatoxin B1 could cause mortalities in juvenile hybrid sturgeon, Acipenser ruthenus $\times$ A. baeri. Aquac. Nutr. 2011, 17, 39-47. [CrossRef]

120. Tuan, N.A.; Grizzle, J.M.; Lovell, R.T.; Manning, B.B.; Rottinghaus, G.E. Growth and hepatic lesions of Nile tilapia (Oreochromis niloticus) fed diets containing aflotoxin B1. Aquaculture 2002, 212, 311-319. [CrossRef]

121. Akter, A.; Rahman, M.; Hasan, M. Effects of aflatoxin B1 on growth and bioaccumulation in common carp fingerling in Bangladesh. Asia Pacif. J. Rural Dev. 2010, 20, 1-13. [CrossRef]

122. Pietsch, C. Zearalenone (ZEN) and its influence on regulation of gene expression in carp (Cyprinus carpio L.) liver tissue. Toxins 2017, 9, 283-298. [CrossRef]

123. Tschirren, L.; Siebenmann, S.; Pietsch, C. Toxicity of ochratoxin to early life stages of zebrafish (Danio rerio). Toxins 2018, 10, 264. [CrossRef]

124. Kępińska-Pacelik, J.; Biel, W. Microbiological hazards in dry fog chews and feeds. Animals 2021, 11, 631. [CrossRef] [PubMed] 
125. Commission Recommendation (EU) 2016/1319 of 29 July 2016 Amending Recommendation 2006/576/EC as Regards Deoxynivalenol, Zearalenone and Ochratoxin A in Pet Food (Text with EEA Relevance). Available online: https://eur-lex.europa.eu/ legal-content/EN/TXT/?uri=CELEX\%3A32016H1319 (accessed on 8 September 2021).

126. Teixeira, E.; Frehse, M.; Freire, R.; Ono, M.; Bordini, J.; Hirozawa, M.; Ono, E. Safety of low and high-cost dry feed intended for dogs in Brazil concerning fumonisins, zearalenone and aflatoxins. World Mycotoxin J. 2017, 10, 273-283. [CrossRef]

127. Shao, M.; Li, L.; Gu, Z.; Yao, M.; Xu, D.; Fan, W.; Yan, L.; Song, S. Mycotoxins in commercial dry pet food in China. Food Addit. Contam. Part B Surveill. 2018, 11, 237-245. [CrossRef]

128. Castaldo, L.; Graziani, G.; Gaspari, A.; Izzo, L.; Tolosa, J.; Rodríguez-Carrasco, Y.; Ritieni, A. Target analysis and retrospective screening of multiple mycotoxins in pet food using UHPLC-Q-Orbitrap HRMS. Toxins 2019, 11, 434. [CrossRef] [PubMed]

129. Uhlig, S.; Ivanova, L.; Voorspoels, P.; Fæste, C.K. In vitro toxicokinetics and phase I biotransformation of the mycotoxin penitrem A in Dogs. Toxins 2020, 12, 293. [CrossRef]

130. Munday, J.S.; Thompson, D.; Finch, S.C.; Babu, J.V.; Wilkins, A.L.; di Menna, M.E.; Miles, C.O. Presumptive tremorgenic mycotoxicosis in a dog in New Zealand, after eating mouldy walnuts. N. Z. Vet. J. 2008, 56, 145-148. [CrossRef]

131. Saleh, I.; Goktepe, I. The characteristics, occurrence, and toxicological effects of patulin. Food Chem. Toxicol. 2019, 129, 301-311. [CrossRef]

132. Zhong, L.; Carere, J.; Lu, Z.; Lu, F.; Zhou, T. Patulin in apples and apple-based food products: The burdens and the mitigation strategies. Toxins 2018, 10, 475. [CrossRef]

133. Wei, C.; Yu, L.; Qiao, N.; Wang, S.; Tian, F.; Zhao, J.; Chen, W. The characteristics of patulin detoxification by Lactobacillus plantarum 13M5. Food Chem. Toxicol. 2020, 146, 111787. [CrossRef]

134. Quinn, B.A.; Crane, T.L.; Kocal, T.E.; Best, S.J.; Cameron, R.G.; Rushmore, T.H.; Farber, E.; Hayes, M.E. Protective activity of different hepatic cytosolic glutathione-S-transferases against DNA-binding metabolites of aflatoxin B1. Toxicol. Appl. Pharmacol. 1990, 105, 351-363. [CrossRef]

135. Gelderblom, W.C.A.; Snyman, S.D. Mutagenicity of potentially carcinogenic mycotoxins produced by Fusarium moniliforme. Mycotoxin Res. 1991, 7, 46-52. [CrossRef] [PubMed]

136. Suneja, S.K.; Ram, G.C.; Wagle, D.S. Effects of T-2 toxin on glucose and tryptophan uptake and intestinal mucosa enzymes. Toxicon 1984, 23, 39-44. [CrossRef]

137. Leni, G.; Cirlini, M.; Jacobs, J.; Depraetere, S.; Gianotten, N.; Sforza, S.; Dall'Asta, C. Impact of naturally contaminated substrates on Alphitobius diaperinus and Hermetia illucens: Uptake and excretion of mycotoxins. Toxins 2019, 11, 476. [CrossRef] [PubMed]

138. Cheli, F. Mycotoxin contamination management tools and efficient strategies in feed industry. Toxins 2020, 12, 480. [CrossRef] 